\title{
Biochemical Patterns of Some Heterotrophic Marine Bacteria Grown in Defined Media
}

\author{
By V. BOFFI \\ Institute of Microbiology, University of Rome, Italy
}

(Accepted for publication 26 September 1968)

\begin{abstract}
SUMMARY
Three heterotrophic marine bacteria, isolated from the Tyrrhenian sea on the basis of their relative growth requirements for acetate and ammonium, were studied mainly in regard to their biochemical and nutritional characters. Data about the amino acid pools, protein amino acids, $\mathrm{CO}_{2}: \mathrm{O}_{2}$ ratios, enzyme activities and sensitivities to metal ions and antibiotics, are reported. The utility of an index obtained from the study of the oxygen uptake with various organic-C concentrations and the use of defined media for a more satisfactory discrimination of the various strains, is shown.
\end{abstract}

\section{INTRODUCTION}

In the marine ecosystem, bacteria play a very important role as consumers and producers of dissolved and particulate organic matter (Wood, 1965). The importance of marine bacteria was pointed out many years ago by ZoBell (1946) and more recently by Wood (1963, 1965) and Kriss (1963); but only in the last few years have marine microbiologists become interested in the more specific problems about the physiology of these micro-organisms. Recently, a considerable amount of work has been done by workers from various countries, because of the interest that marine microbiology has in many different fields (Scholes \& Shewan, 1964). In general, the most recent work of physiological interest deals with the activity of enzyme systems in certain species isolated from the sea (MacLeod \& Hori, I960; Burton \& Morita, 1963; Holmes \& Halvorson, 1965; Shieh, 1965; Campbell, Hellebust \& Watson, 1966; Gundersen, 1966), with their nutritional requirements (MacLeod, Onofrey \& Norris, I954; Tyler, Bielling \& Pratt, I960; Brown, 1960) and with their particular environments (Brown, 1964; MacLeod, 1965). This type of research assumes obviously the identification of isolated strains and in this field, too, significant results have been obtained (Shewan, Hobbs \& Hodgkiss, 1960; Shewan, 1963; Hendrie, Hodgkiss \& Shewan, 1964; Colwell, Citarella \& Ryman, 1965; Pfister \& Burkholder, 1965) without, however, reaching a definition of the problem (Wood, 1967). The present work reports the first results from a systematic study of heterotrophic bacteria of the Mediterranean basin with special reference to the Tyrrhenian sea. The main purpose has been the study of some biochemical characters of the micro-organisms, not only in the method of isolation (which has been achieved on the basis of relative specificity towards defined substrates such as acetate-C and ammonium-N) but also as useful criteria for their identification. 


\section{METHODS}

Sampling. The sampling of the sea water was done along the Tyrrhenian coast, 20 miles out from Torvaianica (Rome), where the depth was $150 \mathrm{~m}$.

The samples were taken by using ZoBell type bottles at the surface $(0 \mathrm{~m}$.) and at 25 and $100 \mathrm{~m}$. depths; in the latter case stainless-steel bottles with internal glass container were used. The samples were kept between $10^{\circ}$ and $15^{\circ}$ and used in the laboratory within about $3 \mathrm{hr}$.

Isolation of bacteria. To $500 \mathrm{ml}$. of the sea water sample were added $5 \mathrm{ml}$. of aged natural sea water (ANSW) containing: $10 \mathrm{mg}$.-atom organic-C as $\mathrm{CH}_{3} \mathrm{COONa} \cdot 3 \mathrm{H}_{2} \mathrm{O}$; $5 \mathrm{mg}$.-atom $\mathrm{NH}_{4}-\mathrm{N}$ as $\left(\mathrm{NH}_{4}\right)_{2} \mathrm{SO}_{4}$ and ro $\mu$ g.-atom $\mathrm{PO}_{4}-\mathrm{P}$ as $\mathrm{K}_{2} \mathrm{HPO}_{4}$. The sample was kept at $\mathrm{I} 8^{\circ}$ in a $\mathrm{I}$ l. flask and after $72 \mathrm{hr}$ a suitable dilution from it was seeded on $1.5 \%$ agar medium containing the same substrates as above. After a few days of incubation the colonies grown were examined and the strains isolated were maintained at $\mathrm{I} 8^{\circ}$ by weekly transfer on the same medium. Three of thejstrains isolated are reported on here; they were labelled as follows: TS/0-3, TS/25-I, TS/IO0-I (TS = Tyrrhenian sea; 0,25 and $100=$ depth in metres; 3 and $I=$ sample number). In the present paper the strains will be indicated by these initials, as our purpose was the study of peculiar physiological characters rather than a taxonomic classification of the species isolated. However, considering the morphological characters reported below and according to the scheme for the identification of Gram-negative rods proposed by Hendrie, Hodgkiss \& Shewan (1964), TS/I00-I can be included in Pseudomonas group II, and TS/0-3 and TS/25-I in Pseudomonas group IV.

Studies on nutritional requirements. The culture media were prepared in ANSW by adding the appropriate substrates and sterilizing at $115^{\circ}$ for $15^{-20} \mathrm{~min}$. These solutions were adjusted to $\mathrm{pH} 7.5$ (glass electrode). After sterilization the $\mathrm{pH}$ value rose to $\mathrm{pH} 7 \cdot 8-8 \cdot \mathrm{I}$. Heat-labile substrates were sterilized by filtration through Millipore filters $(0.45 \mu$ pore size).

The composition of various defined media used will be reported in the Results section, where the concentration of substrates will be also expressed in mg.-atom or in $\mu$ g.-atom of C, N, P per litre according to results of oceanographic analysis (Riley \& Skirrow, 1965).

Media were inoculated by adding $0.1 \mathrm{ml}$. of cultures grown for $72 \mathrm{hr}$ in acetate + ammonium + phosphate medium. These inoculated cultures were incubated at $18^{\circ}$ for 80-90 hr, without agitation, and the degree of growth was measured by extinction at $500 \mathrm{~m} \mu$ in cuvettes of $2 \mathrm{~cm}$. light-path in a PMQ II Zeiss spectrophotometer.

Morphological studies. The three micro-organisms were incubated at $18^{\circ}$ for $60 \mathrm{hr}$ with aeration in ANSW containing acetate-C, $\mathrm{NH}_{4}-\mathrm{N}$ and $\mathrm{PO}_{4}-\mathrm{P}$. The examination of colonies was made after incubation for $72 \mathrm{hr}$ on the acetate + ammonium + phosphate agar already described.

The observation of bacteria by an Orthomat Leitz phase-contrast microscope was preceded by treatment with a drop of $40 \%$ formaldehyde to immobilize motile microorganisms.

The electron-microscope observations were done with a Siemens Elmiskop I A using a drop of bacterial suspension placed on a microscope grid with Formvar membrane with drop of $1.5 \%$ phosphotungstic acid $(\mathrm{pH} 7 \cdot 0)$ added.

Qualitative amino acids chromatography. Eight-litre batches of bacterial cultures 
incubated in acetate + ammonium + phosphate ANSW medium at $18^{\circ}$ for $72 \mathrm{hr}$ with aeration were used. The bacteria were centrifuged at low temperatures, washed three times with ANSW and disintegrated for 10 min. in distilled water at $0^{\circ}$ by ultrasonic treatment in a MSE $60 \mathrm{~W}$. disintegrator. The suspension was then heated at $100^{\circ}$ for $10 \mathrm{~min}$., cooled and a drop of $6 \mathrm{~N}-\mathrm{HCl}$ added. After centrifugation the clear supernatant fluid ( $\mathrm{A}=$ amino acid pool) was used for ion-exchange resin purification, while the precipitated material, washed three times with distilled water, was hydrolysed with $6 \mathrm{~N}-\mathrm{HCl}$ at $110^{\circ}$ for $24 \mathrm{hr}$ in a sealed tube. This coloured solution, dried at reduced pressure, suspended in distilled water and filtered through Whatman no. 42 paper, was subsequently purified $(B=$ protein amino acids).

Five ml. each of A and B solutions were placed, separately, on the tops of the two chromatographic columns (I cm. diameter) containing Amberlite CG-I20 200-400 mesh in the $\mathrm{H}^{+}$form $(40 \mathrm{~cm}$.); $100 \mathrm{ml}$. of freshly distilled water were passed through each column to remove impurities and then $150 \mathrm{ml}$. of $2 \mathrm{~N}-\mathrm{NH}_{4} \mathrm{OH}$ were used to elute the amino acids. The eluates, dried at reduced pressure, dissolved in $0.5 \mathrm{ml}$. distilled water and filtered through a micro-sintered-glass filter, were used for paper chromatography: $0.1 \mathrm{ml}$. was applied to Whatman no. I paper and the chromatograms developed according to the method of Mizzel \& Simpson (I96r).

Manometric measurements. In all experiments the micro-organisms were grown at $18^{\circ}$, with aeration, in 2 l. flasks containing: $1000 \mathrm{ml}$. ANSW, $20 \mathrm{mg}$.-atom total organic-C (acetate + pyruvate + maltose), I0 mg.-atom $\mathrm{NH}_{4}-\mathrm{N}$ and $20 \mu$ g.-atom $\mathrm{PO}_{4}-\mathrm{P}$. After $50 \mathrm{hr}$ the micro-organisms were centrifuged down, washed twice and suspended in $50 \mathrm{ml}$. of sterilized $\mathrm{ANSW}+\mathrm{PO}_{4}-\mathrm{P}$ and kept for $12 \mathrm{hr}$ at $18^{\circ}$ with aeration to deplete the endogenous respiration.

Before use the washed organisms were resuspended in fresh $\mathrm{ANSW}+\mathrm{PO}_{4}-\mathrm{P}$ so that, when diluted $\mathrm{I} / \mathrm{IO}$, the $E_{500 \mathrm{~m} \mu}^{\mathrm{icm}}$ value ranged between 0.4 and 0.5 .

The oxygen uptake and $\mathrm{CO}_{2}$ evolution were measured in a Warburg apparatus at $18^{\circ} \pm 0 \cdot \mathrm{I}$, over the entire experimental period, following the principle of Dickens \& Simer (see Umbreit, Burris \& Stauffer, 1957), but using a different technique. The $\mathrm{pH}$ value in the reaction vessels was about $\mathrm{pH} 7 \cdot 8$, at which value practically all the $\mathrm{CO}_{2}$ was in the bicarbonate form (Riley \& Skirrow, 1965). The amount of $\mathrm{CO}_{2}$ normally present in sea water was determined in separate vessels and then subtracted from the other experimental results.

Crude-extract preparations. Aerated cultures grown at $18^{\circ}$ for $50 \mathrm{hr}$ in 21 . ANSW containing acetate + ammonium + phosphate, as described, were centrifuged and the deposit washed twice with ANSW. The pellets suspended in $7 \mathrm{ml}$. ANSW $+3 \mathrm{ml}$. $0.2 \mathrm{M}$-tris buffer ( $\mathrm{pH} \mathrm{7.4}$ ) were treated in the MSE disintegrator for $5 \mathrm{~min}$. at $0^{\circ}$. The debris was centrifuged down at $30,000 \mathrm{~g}$ for $7 \mathrm{~min}$. and the opalescent supernatant fluid used as crude extract for enzyme assays.

Enzyme assays. The oxidation and reduction of nicotinamide adenine nucleotides with different substrates was done at room temperature by measuring the change in $E_{340 \mathrm{~m} \mu}^{\mathrm{lcm}}$ in spectrophotometer cuvettes (Hilger-Gilford equipment). In a similar way fumarase activity was measured at $300 \mathrm{~m} \mu$ by using 10-20 $\mu$ mole fumarate and I $\mathrm{ml}$. crude extract in $0.05 \mathrm{M}$-tris buffer ( $\mathrm{pH} 7 \cdot 4)$.

Inhibition by heavy metals and antibiotics. The media and inocula were prepared as described for nutritional requirements. The experiments with antibiotics were done in test-tubes containing $4 \mathrm{ml}$. $0.1 \%$ nutrient broth (Difco) in ANSW sterilized at 
I $5^{\circ}$ for $20 \mathrm{~min}$. Penicillin, tetracycline and streptomycin were added in a volume of I ml. of acidified medium at $\mathrm{pH} 4$ to obtain a final $\mathrm{pH}$ of $7 \cdot 2: 0 \cdot 1 \mathrm{ml}$. inocula from serial dilutions of a culture aerated for $36 \mathrm{hr}$ at $\mathrm{I} 8^{\circ}$ with $E_{500 \mathrm{~m} \mu}^{\mathrm{Iom}}=0 . \mathrm{I}$ were obtained by dilution with the same medium.

Substrates and reagents. The amino acids and carbohydrates were purchased from British Drug Houses Ltd. or Mann Res. Lab. Inc., ketoacids and nucleotides were from Sigma or Boehringer, while all the other reagents were from Merck. The sea water for the media was taken in the sampling area and aged in the dark for about 30 days before being used.

\section{RESULTS}

The three strains isolated showed these common characters: straight or curved rods (Pl. I, fig. 4-6), motile with a polar flagellum (P1. 2, fig. 7-9), Gram-negative.

Colonial appearances (Pl. I, fig. I-3) on acetate +ammonium + phosphate agar were as follows.

Organism Ts/0-3: colonies round with an entire margin (Pl. I, fig. I) of yellow colour due to a not diffusible pigment, transparent to transmitted light and opaque to incident light, with a delicate circular structure.

Organism TS/25-I : colonies round with an entire margin, colourless, transparent to transmitted light and opaque to incident light (Pl. I, fig. 2).

Organism TS/I00-I : colonies round with an entire margin, and a dark central core with internal scattered black dots (Pl. I, fig. 3); on acetate + ammonium + phosphate slope a diffusible dark-brown pigment produced.

\section{Nutritional requirements}

Carbon sources. The results obtained with ammonium as nitrogen source and with different carbon substrates are given in Table $I$, in which the data are expressed in arbitrary units of amount of growth related to the extinction. The results show good growth of all three isolates with the following organic-C compounds: starch, glycogen, trehalose, maltose, acetate, pyruvate, oxalacetate. None of the three micro-organisms utilized malic acid and $\alpha$-ketoglutaric acid. Organisms TS/0-3 and TS/25-I did not grow in the presence of the other intermediates of the Krebs cycle, whereas strain TS/IOO-I grew in the presence of citrate, succinate or fumarate. TS/0-3 metabolized maltose but not glucose, TS/25-I gave growth with all carbohydrates tested, and TS/I00-I utilized agar as a carbon source. The negative response to pentoses was typical of all strains, although TS/25-I sometimes grew slightly.

Nitrogen sources. The data about the organic and inorganic nitrogen utilization in the presence or in absence of a carbon source are shown in Tables 2 and 3. The results show that in the presence of acetate-C the three organisms grew with glycine, alanine, valine, leucine, isoleucine and norleucine (leucines), proline, aspartic acid, glutamic acid, arginine or asparagine, but not with norvaline, glutamine or $\alpha$-amino butyric acid.

With inorganic- $\mathrm{N}$, organism Ts/0-3 did not utilize $\mathrm{NO}_{2}-\mathrm{N}$ and $\mathrm{NO}_{3}-\mathrm{N}$ in the presence of acetate-C but, in common with the other strains, it multiplied in ANSW with gelatine added and liquified gelatine in nutrient broth. Less indicative were data obtained in absence of organic- $\mathrm{C}$ by reason of the poor growth reached with single amino acids as source of $\mathrm{C}$ and $\mathrm{N}$. 


\section{General metabolic characteristics}

Amino acids chromatography. A reference chromatogram and two typical chromatographic patterns of strain TS/25-I are shown on Pl. 4, fig. 10-I2.

By substituting acetate- $\mathrm{C}$ with glucose- $\mathrm{C}$ in the culture media, identical results were obtained with the same strain.

\section{Table I. Growth of three heterotrophic marine bacteria on different carbon sources}

The organisms were grown in test-tubes at $18^{\circ}$ in $10 \mathrm{ml}$. of ANSW containing: $10 \mathrm{mg}$.atom/l. of organic-C; $5 \mathrm{mg}$.-atom/l. of $\mathrm{NH}_{4}-\mathrm{N}$ and $20 \mu \mathrm{g}$. atom/l. of $\mathrm{PO}_{4}-\mathrm{P}$. The results are means of duplicate readings. Initial $\mathrm{pH}=8 \cdot 0$; the final $\mathrm{pH}$ values are in parentheses.

\begin{tabular}{|c|c|c|c|}
\hline \multirow[b]{2}{*}{ Carbon sources } & \multicolumn{3}{|c|}{ Organism } \\
\hline & $\mathrm{TS} / 0-3$ & TS/25-I & TS/IOO-I \\
\hline Starch & $2(7 \cdot 23)$ & $4(6 \cdot 50)$ & $4(6 \cdot 30)$ \\
\hline Inulin & 0 & $2(7 \cdot 28)$ & 0 \\
\hline Glycogen & $2(7 \cdot 31)$ & $2(7 \cdot 27)$ & $3(6.50)$ \\
\hline Agar & 0 & 0 & $3(5.80)$ \\
\hline Sucrose & 0 & $4(6 \cdot 0)$ & $3(6 \cdot 60)$ \\
\hline $\mathrm{D}(+)$ Cellobiose & 0 & $3(6 \cdot 54)$ & $3(6 \cdot 80)$ \\
\hline D Trehalose & $3(7 \cdot 22)$ & $3(6.60)$ & $3(6 \cdot 80)$ \\
\hline Lactose & 0 & $3(7 \cdot 27)$ & $2(7 \cdot 3 I)$ \\
\hline Maltose & $2(7 \cdot 28)$ & $4(7 \cdot 00)$ & $3(6 \cdot 57)$ \\
\hline $\mathrm{D}(+)$ Glucose & 0 & $4(6 \cdot 2 I)$ & $3(6.94)$ \\
\hline$D(+)$ Mannose & $1(7 \cdot 27)$ & I $(7 \cdot 40)$ & 0 \\
\hline $\mathrm{D}(+)$ Galactose & 0 & $3(6 \cdot 24)$ & $4(5.60)$ \\
\hline $\mathrm{D}(-)$ Fructose & 0 & $4(6 \cdot 25)$ & 0 \\
\hline $\mathrm{D}(-)$ Mannitol & 0 & $2(6 \cdot 21)$ & $3(6 \cdot 74)$ \\
\hline $\mathrm{D}(+)$ Xylose & 0 & $I(7 \cdot 00)$ & 0 \\
\hline $\mathrm{D}(-)$ Ribose & 0 & $I(7 \cdot 20)$ & 0 \\
\hline $\mathrm{L}(+)$ Arabinose & 0 & I $(7 \cdot 20)$ & 0 \\
\hline Acetate & 2 & 3 & 2 \\
\hline Pyruvate & I & 4 & 4 \\
\hline Citrate & 0 & 0 & 4 \\
\hline$\alpha$-Ketoglutarate & 0 & 0 & 0 \\
\hline Succinate & 0 & 0 & 4 \\
\hline Fumarate & 0 & 0 & 2 \\
\hline DL-Malate & 0 & 0 & 0 \\
\hline Oxalacetate & 2 & 2 & 3 \\
\hline
\end{tabular}

Key to the numbers, $E_{500 \mathrm{~m} \mu}^{2 \mathrm{~cm}} \cdot 0-0 \cdot 03=0: 0 \cdot 03-0 \cdot \mathrm{I}=\mathrm{I}: 0 \cdot \mathrm{I}-0 \cdot 2=2: 0 \cdot 2-0 \cdot 3=3:>0 \cdot 3=4$.

The amino acid composition of all three bacteria are given in Table 4 . It will be noted that aspartic acid and glutamic acid were present in large amounts when acetate-C and $\mathrm{NH}_{4}-\mathrm{N}$ were the only nutrients present in the medium. Strain TS/0-3 differed from the others in that histidine and arginine were absent; TS/25-I had the largest number of amino acids in the pool.

\section{Biochemical activity as measured in the Warburg apparatus}

When nitrogen sources were absent, the consumption rate of oxygen by the starved micro-organisms was substantially different for acetate- $\mathrm{C}$, pyruvate- $\mathrm{C}$ and maltose- $\mathrm{C}$ (Fig. I, 2).

As described in Methods, when the micro-organisms were starved for $12 \mathrm{hr}$ at $18^{\circ}$ 
Table 2. Growth of three heterotrophic marine bacteria on different nitrogen sources in presence of acetate- $C$

Io ml. of ANSW containing: Io mg.-atom/l. of acetate-C; $5 \mathrm{mg}$.-atom/l. of $\mathrm{NH}_{2}-\mathrm{N}$ or $\mathrm{NO}_{3}-\mathrm{N}$ or $\mathrm{NO}_{2}-\mathrm{N}$ or protein-N and $20 \mu \mathrm{g}$.-atom/l. of $\mathrm{PO}_{4}-\mathrm{P}$.

\begin{tabular}{|c|c|c|c|}
\hline $\begin{array}{l}\text { Nitrogen and carbon } \\
\text { sources }\end{array}$ & Ts/o-3 & TS/25-I & TS/100-I \\
\hline \multicolumn{4}{|l|}{ Acetate + } \\
\hline Glycine & 2 & 3 & 4 \\
\hline Alanine & 1 & 2 & 3 \\
\hline Valine & I & I & I \\
\hline Norvaline & 0 & 0 & 0 \\
\hline Leucine & 2 & 2 & 2 \\
\hline Isoleucine & 2 & 2 & 3 \\
\hline Norleucine & 0 & 2 & I \\
\hline Serine & 0 & 2 & 3 \\
\hline Threonine & 0 & 2 & 4 \\
\hline Phenylalanine & 2 & 4 & 3 \\
\hline Tryptophan & 2 & 2 & 0 \\
\hline Cysteine & 0 & 0 & 2 \\
\hline Methionine & 0 & $\mathbf{I}$ & 3 \\
\hline Proline & 2 & 2 & 3 \\
\hline Aspartic acid & 2 & 4 & 3 \\
\hline Glutamic acid & 3 & 4 & 4 \\
\hline Histidine & 0 & 2 & 3 \\
\hline Arginine & 2 & 3 & 2 \\
\hline Glutamine & 0 & 0 & 0 \\
\hline Asparagine & 2 & 3 & 4 \\
\hline$\alpha$-Aminobutyric & 0 & 0 & 0 \\
\hline $\mathrm{NH}_{4}^{+}$ & 2 & 4 & 2 \\
\hline $\mathrm{NO}_{2}^{-}$ & 0 & 2 & $\mathbf{I}$ \\
\hline $\mathrm{NO}_{3}^{-}$ & 0 & 3 & 2 \\
\hline Gelatine & 4 & 4 & 4 \\
\hline $\begin{array}{l}\text { Gelatine-liquef. } \\
\text { + nutrient broth }\end{array}$ & $+(90 \mathrm{~h})$ & $+(48 h)$ & $+(48 h)$ \\
\hline
\end{tabular}

Key and other conditions: see Table I. DL amino acids have been used.

Table 3. Growth of three heterotrophic marine bacteria on amino acids as nitrogen and carbon sources

Io ml. of ANSW containing: $5 \mathrm{mg}$.-atom/1. of $\mathrm{NH}_{2}-\mathrm{N}$ and $20 \mu \mathrm{g}$.-atom/1. $\mathrm{PO}_{4}-\mathrm{P}$

Nitrogen and

Organism

carbon sources

\begin{tabular}{|c|c|c|}
\hline & Organism & \\
\hline $\mathrm{TS} / \mathrm{O}-3$ & $\mathrm{TS} / 25-\mathrm{I}$ & TS/100-I \\
\hline
\end{tabular}

Alanine

Valine

Isoleucine

Serine

$\begin{array}{lll}0 & 1 & 2 \\ 0 & 1 & 0 \\ 0 & 1 & 0 \\ 0 & \text { I } & 0 \\ 0 & \text { I } & 0 \\ 0 & 2 & 0 \\ 2 & 0 & 2 \\ 0 & 0 & 2 \\ 2 & 0 & 1 \\ 2 & 0 & 0 \\ 0 & 1 & 0\end{array}$

Threonine

Phenylalanine

Proline

Aspartic acid

Glutamic acid

Arginine

Asparagine

Key and other conditions: see Table $\mathrm{I}$. The other amino acids gave a negative response. 


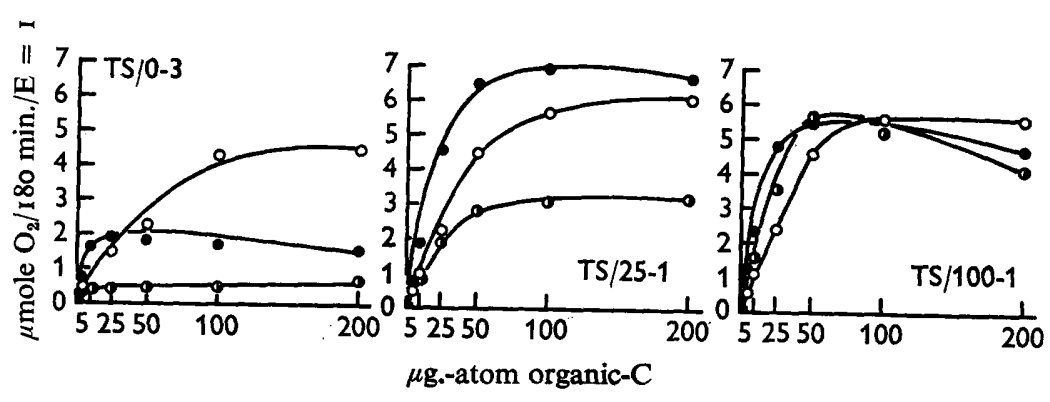

Fig. I. Influence of various organic-C concentrations on the oxygen uptake of three heterotrophic marine bacteria. Each Warburg flask ( $19 \mathrm{ml}$.) contained: in the bottom compartment, $2 \mathrm{ml}$. of bacterial suspension of calculated extinction from 4.0 to 5.0 , and $0.25 \mathrm{ml}$. of organic-C in ANSW; in the centre well, $200 \mu \mathrm{l}$. of $20 \% \mathrm{KOH}$ in distilled water. The final volume was made up to $3 \mathrm{ml}$. with ANSW. Endogenous oxygen has been subtracted. - - AcetateC; O-O, pyruvate-C; $\longrightarrow$ - maltose-C.

\section{Table 4. Chromatographic amino acids composition of three heterotrophic marine bacteria}

First dimension: $\mathrm{n}$-butanol + acetic acid + water, $25+6+25$. Second dimension: methylethylketone $+\mathrm{n}$-butanol + water, $2+2+\mathrm{I}$ by vol.

\begin{tabular}{|c|c|c|c|c|c|c|}
\hline \multirow[b]{3}{*}{$\mathrm{C1} \cdot$} & \multicolumn{3}{|c|}{ Amino acid pools } & \multicolumn{3}{|c|}{ Protein amino acids } \\
\hline & TS/O-3 & $\mathrm{TS} / 25-\mathrm{I}$ & TS/I00-I & TS/O-3 & TS/25-I & TS/IOO-I \\
\hline & + & - & - & + & + & ++ \\
\hline Alanine & + & ++ & ++ & $+t$ & + & ++ \\
\hline Valine & - & + & - & + & + & + \\
\hline Leucines* & + & ++ & + & $+t$ & $+t$ & ++ \\
\hline Serine & - & + & - & + & + & ++ \\
\hline Threonine & + & - & - & + & + & ++ \\
\hline Phenylalanine & - & + & - & + & + & + \\
\hline Methionine & + & $+t$ & + & + & $+t$ & ++ \\
\hline Proline & + & + & + & + & + & + \\
\hline Aspartic acid & + & ++ & +++ & +++ & $t+t$ & +++ \\
\hline Glutamic acid & +++ & +++ & $+t+$ & $+t+$ & $+t+$ & +++ \\
\hline Histidine & - & + & - & - & + & + \\
\hline Lysine & - & ++ & + & + & $+t$ & ++ \\
\hline Arginine & - & - & ++ & - & ++ & ++ \\
\hline Tyrosine & - & + & - & + & + & + \\
\hline Number of & 0 & I & 0 & 3 & 0 & 0 \\
\hline
\end{tabular}

Key:-, absence; + , present in small amounts; ++ , moderate amounts; +++ , large amounts.

* Leucines =leucine, isoleucine, norleucine. These amino acids do not appear well separated, sharing the same tone of blue colour in presence of cyclohexylamine according to Mizzel \& Simpson (196I). Therefore it was not possible to profit by the differences in the colours as for the other amino acids (e.g. glutamic acid, aspartic acid, glycine, arginine, and so on).

with aeration, the endogenous oxygen uptake was very low, showing that the bacteria had exhausted their reserves; when an organic- $C$ source was added, oxygen uptake increased rapidly. Acetate- $\mathrm{C}$ and pyruvate- $\mathrm{C}$ always caused more oxygen to be taken up than maltose (Fig. I), but for organism TS/IOO-I this happened only at high carbon-source concentration. Other experiments showed that when $\mathrm{NH}_{4}-\mathrm{N}$ and $\mathrm{NO}_{3}-\mathrm{N}$ were added to the Warburg vessels the oxygen uptake was the same, while with $\mathrm{NH}_{2}-\mathrm{N}$ (as glycine) more oxygen was taken up. 

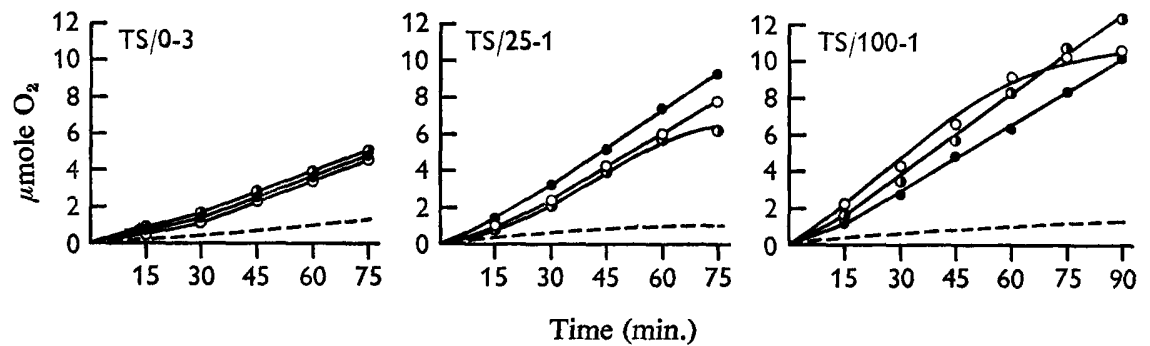

Fig. 2. Oxygen consumption rates, at fixed organic-C concentration, of three heterotrophic marine bacteria. Each Warburg flask ( $19 \mathrm{ml}$.) contained: in the bottom compartment, $2 \mathrm{ml}$. of bacterial suspension $\left(\mathrm{E}_{500 \mathrm{~m} \mu}^{1 \mathrm{~cm}}=3.5\right)$ and $25 \mu \mathrm{g}$-atom of organic-C in $0.25 \mathrm{ml}$. of ANSW; in the centre well, $200 \mu 1$. of $20 \% \mathrm{KOH}$ in distilled water. The final volume was made up to $3 \mathrm{ml}$. with ANSW. Endogenous oxygen has been subtracted. - - O Acetate-C; $\mathrm{O}-\mathrm{O}$, pyruvate- $\mathrm{C}$; - - maltose- $\mathrm{C}$; - - - , endogenous oxygen.
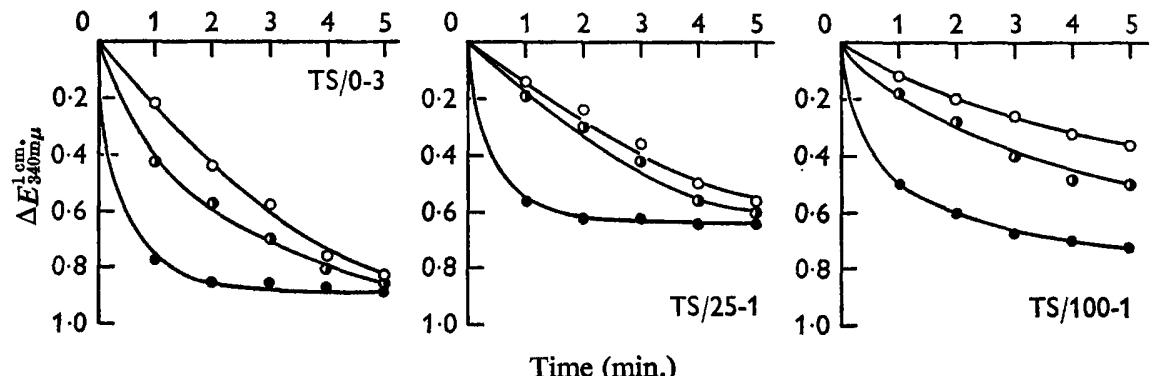

Fig. 3. Enzyme activity on $\mathrm{NADH}_{2}, \mathrm{NADH}_{2}+$ oxalacetate and $\mathrm{NADH}_{2}+$ pyruvate, by cellfree extracts of three heterotrophic marine bacteria. Each spectrophotometer cuvette contained: I ml. of crude extract; I.5-3 $\mu$ mole of $\mathrm{NADH}_{2} ; 10 \mu$ mole of substrate and $0.05 \mathrm{M}$ tris buffer at $\mathrm{pH} 7.4$ in a total volume of $3.5 \mathrm{ml}$. with distilled water. $\mathrm{O}-\mathrm{O}, \mathrm{NADH}_{2}$; $\longrightarrow-1 \mathrm{NADH}_{2}+$ pyruvate, $\longrightarrow \mathrm{NADH}_{2}+$ oxalacetate.

\section{Table 5. Ratio $\mathrm{CO}_{2}: \mathrm{O}_{2}$ and carbon sources for three heterotrophic marine bacteria}

For $\mathrm{CO}_{2}$ evolution each Warburg flask $(7.5 \mathrm{ml}$.) contained: in the bottom compartment, $50 \mu \mathrm{l}$. of $\mathrm{KOH}$ collected from the centre well of the flasks used for $\mathrm{O}_{2}$ uptake, and $0.45 \mathrm{ml}$. of distilled water. In the side arm, $0.5 \mathrm{ml}$. of $3 \mathrm{~N}-\mathrm{HCl}$. After equilibrium, the $\mathrm{HCl}$ was transferred to the bottom compartment and $\mathrm{CO}_{2}$ evolved after $20 \mathrm{~min}$. was recorded. For $\mathrm{O}_{2}$ uptake, see Fig. 2.

\begin{tabular}{|c|c|c|c|c|c|c|}
\hline \multirow{2}{*}{$\begin{array}{l}\text { Carbon } \\
\text { sources }\end{array}$} & \multicolumn{2}{|c|}{$\mathrm{TS} / 0-3$} & \multicolumn{2}{|c|}{$\mathrm{TS} / 25-\mathrm{I}$} & \multicolumn{2}{|c|}{ TS/IOO-I } \\
\hline & S.v.* & M.v. $\uparrow$ & S.v. & M.v. & S.v. & M.v. \\
\hline Acetate & $\left.\begin{array}{l}I \cdot 88 \\
2 \cdot 42 \\
I \cdot 46\end{array}\right\}$ & $1.92 \pm 0.27$ & $\left.\begin{array}{l}I \cdot 08 \\
I \cdot 06 \\
I \cdot 27\end{array}\right\}$ & $I \cdot I 3 \pm 0.07$ & $\begin{array}{l}0.78 \\
0.90 \\
1.08\end{array}$ & $0.92 \pm 0.09$ \\
\hline Pyruvate & $\left.\begin{array}{l}2 \cdot 14 \\
2 \cdot 35 \\
1 \cdot 96\end{array}\right\}$ & $2 \cdot I 5 \pm 0.1 I$ & $\left.\begin{array}{l}1 \cdot 4^{8} \\
1 \cdot 64 \\
1 \cdot 91\end{array}\right\}$ & $1.67 \pm 0.28$ & $\left.\begin{array}{l}I \cdot 5 I \\
I \cdot 3 I \\
I \cdot 27\end{array}\right\}$ & $1 \cdot 37 \pm 0.07$ \\
\hline Maltose & $\left.\begin{array}{l}0.78 \\
0.90 \\
1.08\end{array}\right\}$ & $0.92 \pm 0.09$ & $\left.\begin{array}{l}I \cdot 25 \\
I \cdot 24 \\
I \cdot 40\end{array}\right\}$ & $1 \cdot 30 \pm 0 \cdot 16$ & $\left.\begin{array}{l}0.71 \\
0.67 \\
0.59\end{array}\right)$ & $0.65 \pm 0.01$ \\
\hline
\end{tabular}

* Single value. $\uparrow$ Mean value \pm standard error. 


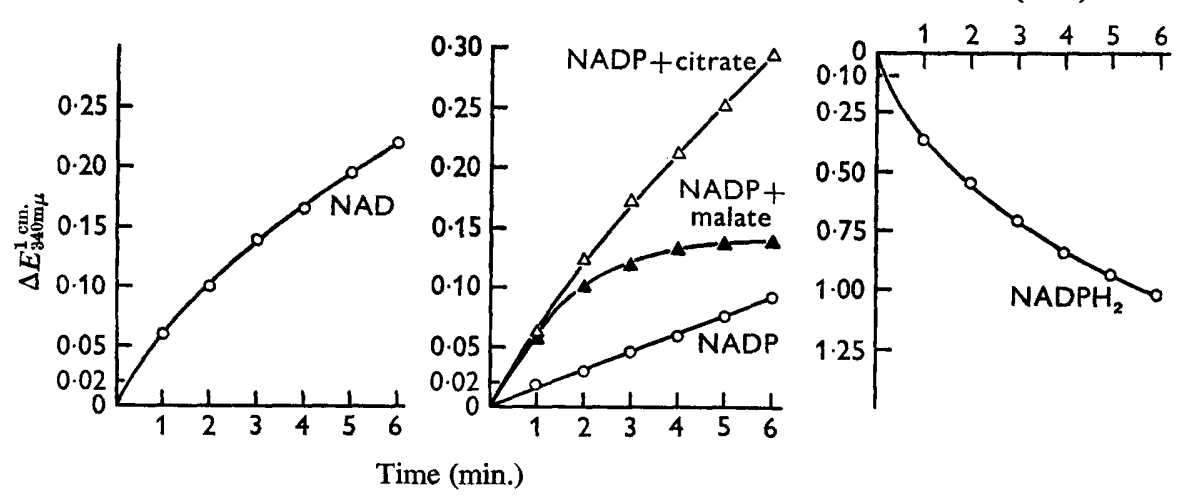

Fig. 4. Enzyme activity on NAD, NADP, $\mathrm{NADH}_{2} \mathrm{NADP}$ + malate and NADP + citrate, by cell-free extract of strain TS/25-I. Experimental conditions as in Fig. 3.

Table 6. Enzyme activities in sonicated cell-free extracts of three heterotrophic marine bacteria

Each cuvette contained in $3.5 \mathrm{ml}$.: I ml. of crude extract, Io $\mu$ mole of substrate, $\mathrm{I} \cdot 5-3 \mu$ mole of nucleotide in $0.05 \mathrm{M}$-tris buffer at $\mathrm{pH} 7 \cdot 4$.

\begin{tabular}{|c|c|c|c|}
\hline \multirow[b]{2}{*}{ Coenzymes and substrates } & \multicolumn{3}{|c|}{ Micro-organisms } \\
\hline & Ts/0-3 & $\mathrm{TS} / 25-\mathrm{I}$ & $\mathrm{TS} / 100-1$ \\
\hline $\begin{array}{l}\mathrm{NADH}_{2} \\
\mathrm{NADPH}_{2}\end{array}$ & $\begin{array}{l}+++ \\
+++\end{array}$ & $\begin{array}{l}+++ \\
+++\end{array}$ & $\begin{array}{c}++ \\
+\end{array}$ \\
\hline $\begin{array}{l}\text { NAD } \\
\text { NADP }\end{array}$ & $\begin{array}{c}++ \\
-\end{array}$ & $\begin{array}{c}++ \\
+\end{array}$ & $\begin{array}{c}++ \\
+\end{array}$ \\
\hline $\begin{array}{l}\mathrm{NADH}_{2}+\text { pyruvate } \\
\mathrm{NADH}_{2}+\text { oxalacetate }\end{array}$ & $\begin{array}{l}+++ \\
+++\end{array}$ & $\begin{array}{l}+++ \\
+++\end{array}$ & $\begin{array}{l}+++ \\
+++\end{array}$ \\
\hline $\begin{array}{l}\text { NAD + malate } \\
\text { NAD }+\alpha \text {-ketoglutarate }\end{array}$ & $\begin{array}{c}++ \\
-\end{array}$ & $\begin{array}{c}++ \\
-\end{array}$ & - \\
\hline $\begin{array}{l}\text { NADP + citrate } \\
\text { NADP + malate } \\
\text { NADP }+\alpha \text {-ketoglutarate } \\
\text { Fumarate }\end{array}$ & $\begin{array}{l}- \\
- \\
-\end{array}$ & $\begin{array}{c}+++ \\
++ \\
- \\
+\end{array}$ & $\begin{array}{l}- \\
- \\
-\end{array}$ \\
\hline
\end{tabular}

Key: +++ , high activity; ++ , moderate activity; + , low activity; - , absence of activity.

The values for $\mathrm{CO}_{2}: \mathrm{O}_{2}$ ratios of the three organic-C sources (Table 5) were obtained from the experiments illustrated in Fig. 2. These results show that the ratios were higher for pyruvate-C and lower for maltose-C for organisms Ts/0-3 and TS/IO0-I, but, for $\mathrm{TS} / 25$-I this latter value was intermediate between acetate-C and pyruvate-C.

Enzyme activities in crude extract experiments. In Fig. 3 the rates of change in extinction $(\Delta E)$ at $340 \mathrm{~m} \mu$ obtained with cell-free extracts of the three bacteria are shown. The results show that when oxalacetate or pyruvate were added to sonicated soluble fractions, the rate of $\mathrm{NADH}_{2}$ oxidation was greater than in the controls. Data about the NAD and NADP reduction and $\mathrm{NADPH}_{2}$ oxidation by cell-free extracts of organism TS/25-I are given in Fig. 4, which shows the enzyme activity 
towards citrate or malate. The results of all experiments on enzyme activity in crude extracts are summarized in Table 6.

Effect of some inhibitors. From the data presented in Table 7 it can be seen that organism TS/0-3 was the most sensitive to inhibition by heavy metal ions; in general, $\mathrm{Cu}^{2+}$ and $\mathrm{Zn}^{2+}$ were the most inhibitory ions. None of the metals tested stimulated the growth of the three organisms under the experimental conditions adopted. As shown in Fig. 5, the three organisms were in general fairly resistant to antibiotics under the described conditions. Organisms $\mathrm{TS} / 0-3$ and $\mathrm{TS} / 25$-I were sensitive to penicillin when the inoculum was small; with larger inocula all the organisms showed a clear resistance; especially $\mathrm{TS} / 25$-I and $\mathrm{TS} / \mathrm{I00}-\mathrm{I}$ towards penicillin, and $\mathrm{TS} / 0-3$ towards tetracycline.
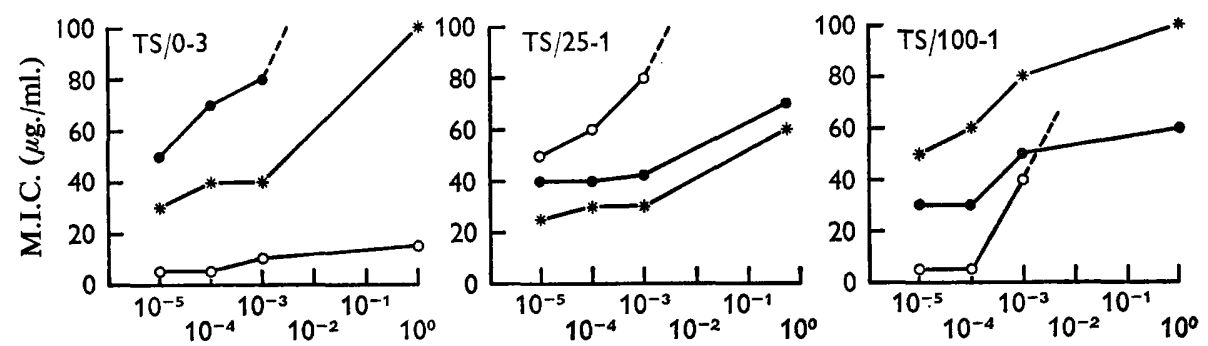

Dilution of inoculum

Fig. 5. Minimum inhibitory concentration (M.I.C.) of penicillin, tetracycline and streptomycin, on three heterotrophic marine bacteria, at various inoculum densities. Experimental conditions, see methods. The values represent the mean of duplicate readings. $\mathrm{O}-\mathrm{O}$, penicillin; - - , tetracycline; *ـ, streptomycin.

Table 7. Effect of heavy metal ions on growth of three heterotrophic marine bacteria

\begin{tabular}{|c|c|c|c|c|}
\hline \multirow[b]{2}{*}{ Metal ions } & \multirow[b]{2}{*}{$\mu$ g.-atom $/$ l. } & \multicolumn{3}{|c|}{ Micro-organisms } \\
\hline & & $\mathrm{TS} / 0-3$ & $\mathrm{TS} / 25-\mathrm{I}$ & TS/IOO-I \\
\hline & & 2 & 3 & 2 \\
\hline $\mathrm{Cu}^{2+}$ & $0 . \mathrm{I}$ & 2 & 3 & 2 \\
\hline $\mathrm{Cu}^{2+}$ & $1 \cdot 0$ & I & 3 & I \\
\hline $\mathrm{Cu}^{2+}$ & 10 & 0 & 2 & 0 \\
\hline $\mathrm{Fe}^{8+}$ & $0 . \mathrm{I}$ & 2 & 3 & 2 \\
\hline $\mathrm{Fe}^{8+}$ & $I \cdot O$ & 2 & 3 & 2 \\
\hline $\mathrm{Fe}^{3+}$ & 10 & 2 & 3 & 2 \\
\hline $\mathrm{Mn}^{2+}$ & 0.1 & I & 3 & 2 \\
\hline $\mathrm{Mn}^{2+}$ & $I \cdot O$ & 2 & 3 & 2 \\
\hline $\mathrm{Mn}^{2+}$ & 10 & I & 3 & 2 \\
\hline $\mathrm{Zn}^{2+}$ & $0 . \mathrm{I}$ & I & 3 & 2 \\
\hline $\mathrm{Zn}^{2+}$ & $1 \cdot 0$ & I & 3 & 2 \\
\hline $\mathrm{Zn}^{2+}$ & 10 & 0 & 2 & $\mathbf{I}$ \\
\hline $\mathrm{MoO}_{4}^{2-}$ & 0.1 & I & 3 & 2 \\
\hline $\mathrm{MoO}_{4}^{2-}$ & $I \cdot 0$ & I & 3 & $\mathbf{I}$ \\
\hline $\mathrm{MoO}_{4}^{2-}$ & 10 & I & 3 & 2 \\
\hline $\mathrm{Co}^{2+}$ & $0 . \mathrm{I}$ & I & 3 & 2 \\
\hline $\mathrm{Co}^{3+}$ & $1 \cdot 0$ & I & 3 & 2 \\
\hline $\mathrm{Co}^{2+}$ & 10 & I & 3 & $\mathbf{I}$ \\
\hline
\end{tabular}

Key and other conditions: see Table I. 


\section{DISCUSSION}

The conditions used in the isolations of the bacteria were based on the principle of selection under minimal nutrient conditions (acetate + ammonium + phosphate) at the temperature of the sea water in the sampling area (I 5 to $\left.18^{\circ}\right)$. In this way all the strains isolated shared the relative specificity of a nutritional character. Although the specificity towards a substrate might depend upon the physiological conditions of the micro organism at time of sampling, and the use of such a principle for strain isolation might be questionable (Hungate, 1962; Hayaishi, 1955), the bacteria isolated in this way have kept, during the time of the research ( 16 months), the property of multiplying on acetate-C and ammonium-N. This property has proved to be stable. Future work will test whether this principle might be of use in grouping different strains of marine bacteria according to their relative specificity towards defined substrates.

Morphological characters. The photographs given were chosen as the most typical; but very often, especially for organisms TS/0-3 and TS/IO0-I, very different shapes were observed. In fact, curved forms were frequently observed and this could have been considered as characteristic of the genus Vibrio. However, in accord with the Hendrie scheme, based on behaviour of micro-organisms towards glucose-containing medium and the pteridine $0 / 129$, this possibility was excluded and the organisms recognized as belonging to the genus Pseudomonas. However, further morphological observations, made on different strains successively isolated, showed that the vibrio shape was attributable to a stage in division in which the bacteria showed an inflexion before dividing in two. These data are in agreement with the criticism made by Rhodes (1965) and by Wood (1967) on the morphological characters of bacteria used in taxonomic studies. One character, on the contrary, which has shown a noticeable constancy, at least in the experimental conditions used, is the shape and pigmentation of the colonies on acetate + ammonium agar: organism Ts/0-3 yellow: TS/25-I colourless; Ts/100-I black-brown, although the appearance of colourless variants was occasionally noted.

Nutritional characters. Results obtained from study of nutritional requirements were distinctive under the experimental conditions used. Organism TS/100-I possessed characters quite different from the other two organisms in that it used agar, citrate, succinate, fumarate and, with the exception of lactose, produced acid from the carbohydrates. Organism Ts/0-3 had the singular character of using maltose but not glucose and it did not use $\mathrm{NO}_{3}-\mathrm{N}$ and $\mathrm{NO}_{2}-\mathrm{N}$. An interesting property common to the three organisms was the non-utilization of malate, $\alpha$-ketoglutarate or glutamine. Apart from the consideration of substrate permeability, the non-utilization of glutamine could be due to the lack of glutaminase, which hydrolyses glutamine to glutamic acid and ammonia (Cohen \& Sallach, I96I; Roberts, I960).

Hence clear differences in cultural behaviour exist among the three microscopically similar organisms.

General biochemical characters. This little-known aspect of marine bacteria was studied to compile biochemical properties of eventual general interest and to try to relate some positive or negative characters common to the three organisms with their relative specificity to acetate and ammonium. Obviously the data given here are not sufficient to clarify the metabolic activities of the organisms for the various substrates, but their utility in bringing out the differences is evident. Chromatography of pools 
of amino acids has been used sometimes for taxonomic studies (Holden, 1962). Taking into account the experimental conditions used for growth and extraction, some significant differences were found in the amino acid pools of the three strains (Table 4). These differences cannot be easily interpreted biochemically, but should be useful, when a sufficient variety of marine bacteria have been examined, to judge whether the composition of amino acid pools is helpful in their classification.

The Warburg experiments clearly indicate differences among the three strains in the rates of oxygen uptake from various carbon sources, particularly with acetate. Starved cells were used because endogenous respiration was then very low; with not-starved cells, endogenous respiration was so high that the differences in the oxygen uptake with different substrates were less marked.

Assuming that the micro-organisms did not multiply in the Warburg flasks, Fig. I may be used to calculate a substrate affinity constant resembling Michaelis-Menten's kinetic constant for the enzymes. Half-maximum reaction rates correspond, for the three strains with acetate-C, to values (in molar units) of: $\mathrm{TS} / 0-3, \mathrm{~K}_{\text {acet. }}=\mathrm{I} \cdot 6 \times \mathrm{IO}^{-3}$; $\mathrm{TS} / 25-\mathrm{I}, \mathrm{K}_{\text {acet. }}=5.6 \times 10^{-3} ; \mathrm{TS} / \mathrm{IOO}-\mathrm{I}, \mathrm{K}_{\text {acet. }}=2.7 \times \mathrm{IO}^{-3}$. The reproducibility of these values was indicated by other experiments made with similar strictly controlled experimental conditions: for pyruvate ( $25 \mu \mathrm{g}$./Warburg vessel) the oxygen uptakes, over $60 \mathrm{~min}$., were respectively: $58-66-55 \mu \mathrm{l}$. for TS/0-3; II6-I34-I $23 \mu \mathrm{l}$. for TS/25-I ; I65-198-I70 $\mu \mathrm{l}$. for TS/100-I, where the values are the means of duplicate tests in three independent experiments.

In spite of the approximate nature of these values it appears that differences in the substrate affinity are sufficient to differentiate the three strains despite their specificity for the same substrate. The ratios $\mathrm{CO}_{2}: \mathrm{O}_{2}$ obtained with the same substrates are also significantly different for the three micro-organisms, which presumably reflects differences in the metabolism of these substrates under starved conditions. Values below I indicate a prevalence of oxidative processes and agree very well with the $\mathrm{pH}$ values for various strains shown in Table $\mathrm{r}$. The $\mathrm{CO}_{2}: \mathrm{O}_{2}$ ratio is thus important in marine bacterial respiration, but it is not yet clear whether such values will be useful in taxonomic studies as proposed by Katznelson \& Robinson (I956) for halophilic strains.

The redox potential of these systems did not correlate with $\mathrm{CO}_{2}: \mathrm{O}_{2}$ ratios. With TS/I00-I strain, for example, the initial value of $E_{h}$ was $+330 \mathrm{mV}$. at $\mathrm{pH} 8 \cdot 0$ (slightly different from the value of $+322 \mathrm{mV}$. at $20^{\circ}$ and at $\mathrm{pH} 8.15$ for the sea water in the sampling area at $\circ \mathrm{m}$. Of course, the $E_{h}$ of this bacterial system changed during the experiments and after $24 \mathrm{hr}$ it was $+160 \mathrm{mV}$. with little differences for acetate, pyruvate and maltose.

Experiments on cell-free extracts have been recently employed by some authors (De Vries \& Stouthamer, 1967; Joyner \& Baldwin, I966) to get indications on the taxonomy and ecology of many non-marine micro-organisms, but the significance of these researches depends strictly on the use of well-defined experimental conditions. The synthesis of many enzymes in bacteria represent an adaptation phenonemon (Daron, 1967) and the nutritional conditions influence the enzyme synthesis of the tricarboxylic acid cycle (Hanson \& Cox, 1967). Despite the limited purification of the extracts and the possible differences in the optimal conditions required for the similar enzyme activities in various strains, the experiments reported here with cell-free extracts have shown their utility by demonstrating the presence of some enzyme activities which were not recognizable with Warburg experiments. For example, in 
preliminary experiments, suspensions of sonicated marine bacteria did not take up any oxygen with pyruvate, citrate or succinate, whereas by direct spectrophotometry these enzyme activities were indicated. Presumably some enzyme systems of the terminal electron transport mechanisms were inactivated by ultrasonics or removed by centrifugation.

A particular substrate and pyridine nucleotides evoked enzyme activities related to Krebs cycle in the TS/25-I extract. The apparent absence of comparable activities in extracts of Ts/0-3 and TS/IOO-I was probably because the majority of these enzymes do not link to NAD or NADP and require an artificial acceptor for the measurement of activity. As already emphasized by Ochoa \& Stern (1952) and Barret \& Kallio (1953), such experiments as these do not prove that the Krebs cycle is really the route used in vivo for terminal carbohydrate metabolism. The results of nutritional and cellfree extract experiments indicate that the non-utilization of citrate, succinate, fumarate and malate by TS/25-I as sole carbon source in the presence of ammonium nitrogen could be attributable to inducible permeation systems (Kogut \& Podoski, I953; Barret \& Kallio, 1953).

Growth inhibitors. Antibiotic sensitivity has been recently adopted by Pfister \& Burkholder (1965) as a discriminating character among marine strains and Shewan (1963) used pteridine o/I29 as a differential test of Gram-negative asporogenous marine rods.

The experiments with metal ions reported in Table 7 show a significant difference between strain Ts/25-I, which is practically insensitive, and strain TS/0-3, which is the most sensitive. The experiments with antibiotics were carried out in a complex medium, instead of a defined one as generally used with non-marine strains. Only penicillin showed a clear difference in sensitivity between TS/25-I and the other two bacteria; this strain was, however, sensitive when the inoculum was low.

All three strains showed apparent resistance to tetracycline and streptomycin, but the ease with which these drugs, especially tetracycline, form complexes with $\mathrm{Ca}^{2+}$ and $\mathrm{Mg}^{2+}$ that lower antibacterial activity (Laskin, 1967), suggests that these two antibiotics are of little use in sea-water media which contain $\mathrm{Mg}^{2+}$ and $\mathrm{Ca}^{2+}$ ions.

Finally, a common characteristic of the three strains was their incapability of multiplying with malic acid or $\alpha$-ketoglutaric acid. This property was not shown by some terrestrial strains of pseudomonas, classified, according Hendrie et al. (1964), into groups I (three strains), II (two strains) and IV (one strain), all of which grew very well after $24 \mathrm{hr}$ at $37^{\circ}$ with ammonium nitrogen and malic acid or $\alpha$-ketoglutaric acid. This interesting nutritional characteristic of these marine bacteria has been confirmed by the isolation of eight other strains which behave similarly. Hence the use of particular defined media for the isolation of marine bacteria sharing characteristic biochemical properties is important and may in future assist the identification of newly isolated strains.

I am particularly grateful to Professor A. Cimmino, Director of the Institute of Microbiology, and to Professor A. Rossi-Fanelli, Director of the Institute of Biological Chemistry, of the University of Rome, for their encouragement, assistance and suggestions during the course of this work.

I wish to thank the Harbour Office of Rome and Fiumicino for their kind collabora- 
tion in the sampling of sea water, Mr V. Strippoli for technical assistance and $\mathrm{Mr}$ M. Mari for the electron micrographs.

This work was supported by research contract no. I I5/1323/I390 from the Consiglio Nazionale delle Ricerche (C.N.R.).

\section{REFERENCES}

BARRET, J. T. \& KALLIO, R. E. (1953). Terminal respiration in Pseudomonas fluorescens: component enzymes of the tricarboxylic acid cycle. J. Bact. 66, 517.

BRown, A. D. (1960). Some properties of a Gram-negative heterotrophic marine bacterium. J. gen. Microb. 23, 471 .

Brown, A. D. (1964). Aspect of bacterial response to the ionic environment. Bact. Rev. 28, 296.

BurTon, S. D. \& MorITA, R. Y. (1963). Denaturation and renaturation of malic dehydrogenase in a cell-free extract from a marine psycrophyle. J. Bact. 86, I0I9.

Campbell, A. E., Hellebust, J. A. \& Watson, S. W. (I966). Reductive pentose phosphate cycle in Nitrocystis oceanus. J. Bact. 9x, I 178.

Cohen, P. P. \& Sallach, H. J. (1961). Nitrogen metabolism of amino acids. In Metabolic Pathways. Ed. by D. M. Greenberg. Vol. 2. New York: Academic Press Inc.

Colwell, R. R., Citarella, R. V. \& Ryman, I. (1965). Deoxyribonucleic acid base composition and Adansonian analysis of heterotrophic, aerobic Pseudomonas. J. Bact. 90, I 148.

Daron, H. H. (1967). Occurrence of isocitrate lyase in a thermophilic Bacillus species. J. Bact. 93, 703.

De VRIES, W. \& Stouthamer, H. (1967). Pathway of glucose fermentation in relation to the taxonomy of Bifidobacteria. J. Bact. 93, 574.

GUNDERSEN, K. (1966). The growth and respiration on Nitrocystis oceanus at different partial pressure of oxygen. J. gen. Microb. 42, 387.

Hanson, R. S. \& Cox, D. P. (1967). Effect of different nutritional conditions of the synthesis of tricarboxylic acid cycle enzymes. J. Bact. 93, 1777.

HAYAISH, O. (I955). Special techniques for bacterial enzymes. Enrichment culture and adaptive enzymes. Meth. Enzymol. x, 126.

HendrIe, M. S., Hodgkiss, W., \& Shewan, J. M. (1964). Considerations on organisms of the Achromobacter-Alcaligenes group. Annls Inst. Pasteur, Lille. 15, 43.

Holden, J. T. (1962). The composition of microbial amino acid pools. In Amino Acid Pools, Ed. by J. T. Holden. Amsterdam: Elsevier Publ. Co.

Holmes, P. K. \& Halvorson, H. O. (1965). Purification of a salt requiring enzyme from an obligately halophilic bacterium. $J$. Bact. 90, 312 .

Hungate, R. E. (1962). Ecology of bacteria. In The Bacteria. Ed. by I. C. Gunsalus and R. Y. Stanier. Vol. 4. New York: Academic Press Inc.

JoYNER, A. E. JUN. \& BALDWIN, R. L. (I966). Enzymatic studies of pure cultures of rumen microorganisms. J. Bact. 92, 1321 .

KATZNELSON, H. \& ROBINSON, J. (1956). Observations on the respiratory activity of certain obligately halophilic bacteria with high salt requirements. J. Bact. 7r, 244.

KrIss, A. E. (I963). Marine Microbiology. Deep-Sea. Translation by J. M. Shewan and Z. Kabata. Edinburgh: Oliver Boyd.

KogUt, M. \& PoDoski, E. P. (1953). Oxidative pathways in a fluorescent Pseudomonas. Biochem. J. 55,800 .

LASKIN, A. I. (1967). Tetracyclines. In Antibiotics, Mechanism of Action, Ed. by D. Gottlieb and P. D. Shaw. Vol. I, Jena: Springer-Verlag.

MACLEOD, R. A. (1965). The question of the existence of specific marine bacteria. Bact. Rev. 29, 9.

MACLEOD, R. A. \& HoRI, A. (1960). Nutrition and metabolism of marine bacteria. VIII. Tricarboxylic acid cycle enzymes in a marine bacterium and their response to added salt. J. Bact. 8o, 464 .

MAcLeod, R. A., ONofrey, E. \& Norris, M. E. (1954). Nutrition and metabolism of marine bacteria. I. Survey of nutritional requirements. J. Bact. 68, 680 .

Mizzel, M. \& Simpson, B. S. (I961). Paper chromatographic separation of amino acids. A solvent to replace phenol. J. Chromat. 5, I57.

OCHOA, S. \& STERN, J. R. (1952). Carbohydrate metabolism. A. Rev. Biochem. 2I, 547. 
Pfister, R. M. \& BURKholder, P. R. (1965). Numerical taxonomy of some bacteria isolated from antarctic and tropical sea-waters. J. Bact. 9o, 863.

Rhodes, M. E. (1965). Flagellation as criterion for the classification of bacteria. Bact. Rev. 29, 442.

RILeY, J. P. \& SkIRrow, G. (1965). Chemical Oceanography, vol. I. New York: Academic Press.

RoBerTs, E. (1960). Glutaminase. In The Enzymes. Ed. by P. D. Boyer, H. Lardy and K. Myrback. Vol. 4. New York: Academic Press.

SCHOLEs, R. B. \& ShewAN, J. M. (1964). The present status of some aspects of marine microbiology. In Advances in Marine Biology. Ed. by F. S. Russel. Vol. 2. New York: Academic Press.

SHEWAN, J. M. (1963). The differentiation of certain genera of Gram-negative bacteria frequently encountered in the marine environment. Symposium on Marine Microbiology. Springfield, Ill.: C. Thomas.

ShewAN, J. M., HobBs, G. \& Hodgkiss, W. (1960). A determinative scheme for the identification of certain genera of Gram-negative bacteria with special reference to the Pseudomonadaceae. J. appl. Bact. 23, 379.

SHIEH, H. S. (1965). Further studies on the oxidation of betaine by a marine bacterium: Achromobacter cholinophagum. Can. J. Microb. 12, 299.

Tyler, M. E., Bielling, M. G. \& PratT, D. B. (I960). Mineral requirements and other characters of selected marine bacteria. J. gen. Microb. 23, I53.

Umbreit, W. W., Burris, R. H. \& Stauffer, J. F. (1957). Manometric Technique. Minneapolis: Burgess Publ. Co.

Wood, E. J. F. (1963). Heterotrophic microorganisms in the oceans. Oceanogr. Mar. Biol. Ann. Rev. I, 197.

Wood, E. J. F. (1965). Marine'Microbial Ecology. London: Chapman \& Hall.

Woon, E. J. F. (1967). Microbiology of Oceans and Estuaries. Amsterdam: Elsevier, Publ. Co.

ZoBel., C. E. (1946). Marine Microbiology. Waltham, Mass.: Chronica Botanica Press. 


\section{EXPLANATION OF PLATES}

\section{Plate I}

Fig. 1. Micrograph of colonies of strain Ts/0-3.

Fig. 2. Micrograph of colonies of strain TS/25-I.

Fig. 3. Micrograph of one colony of strain TS/100-I.

Fig. 4. Phase-contrast micrograph of strain Ts/0-3. $\times 1500$.

Fig. 5. Phase-contrast micrograph of strain Ts/25-I. $\times 1500$.

Fig. 6. Phase-contrast micrograph of strain Ts/100-1. $\times$ I500.

\section{Plate 2}

Fig. 7. Electron micrograph of strain Ts/0-3.

Fig. 8. Electron micrograph of strain $\mathrm{TS} / 25-\mathrm{I}$.

Fig. 9. Electron micrograph of strain TS/100-I.

\section{Plate 3}

Fig. 10. Amino acids standard chromatogram.

Fig. I I. Amino acids pool chromatogram of strain Ts/25-1.

Fig. I2. Protein amino acids chromatogram of strain Ts/25-I. 
Journal of General Microbiology, Vol. 55, No. 2

Plate I
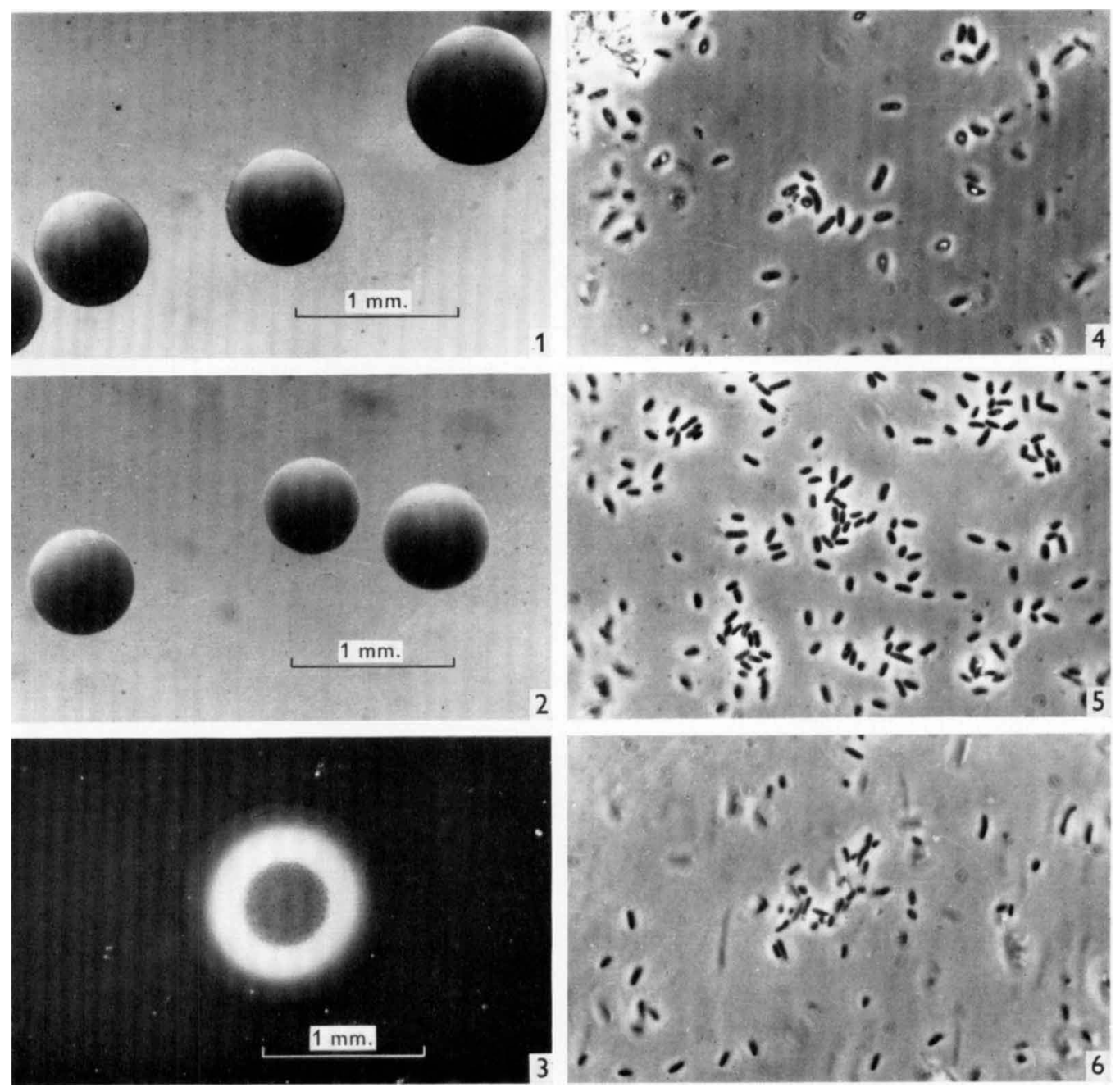

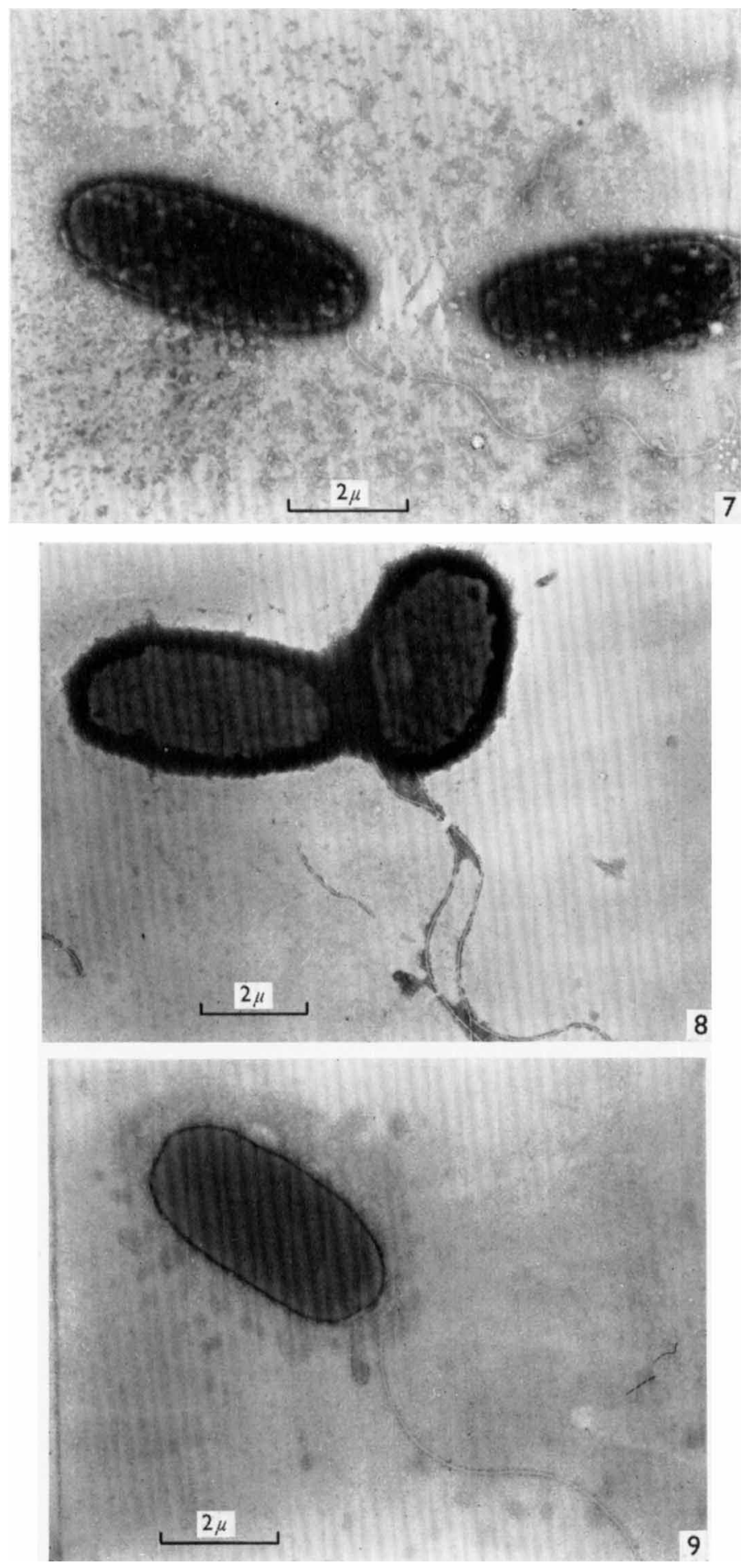


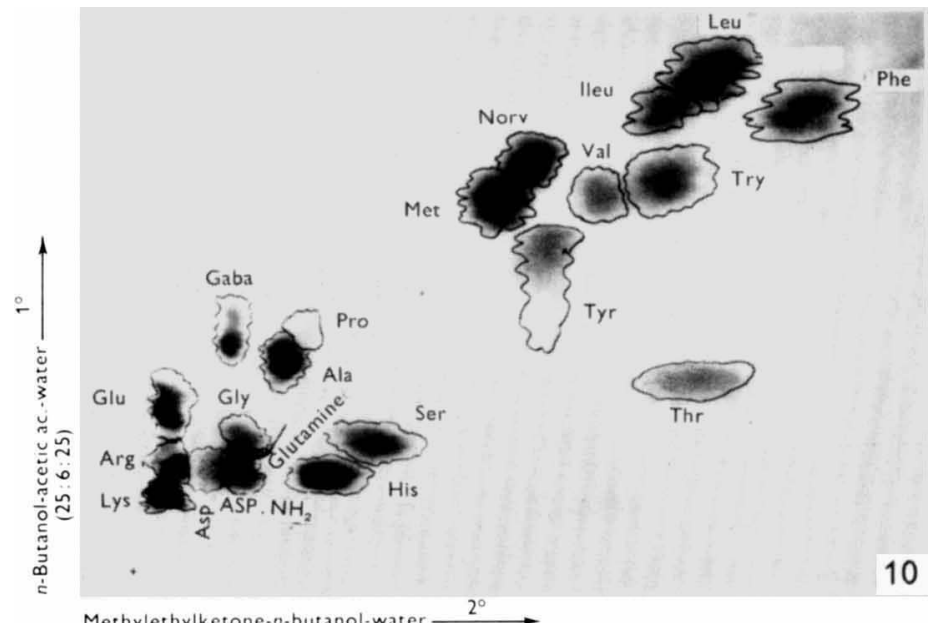

Methylethylketone-n-butanol-water $\longrightarrow$

$(2: 2: 1)$
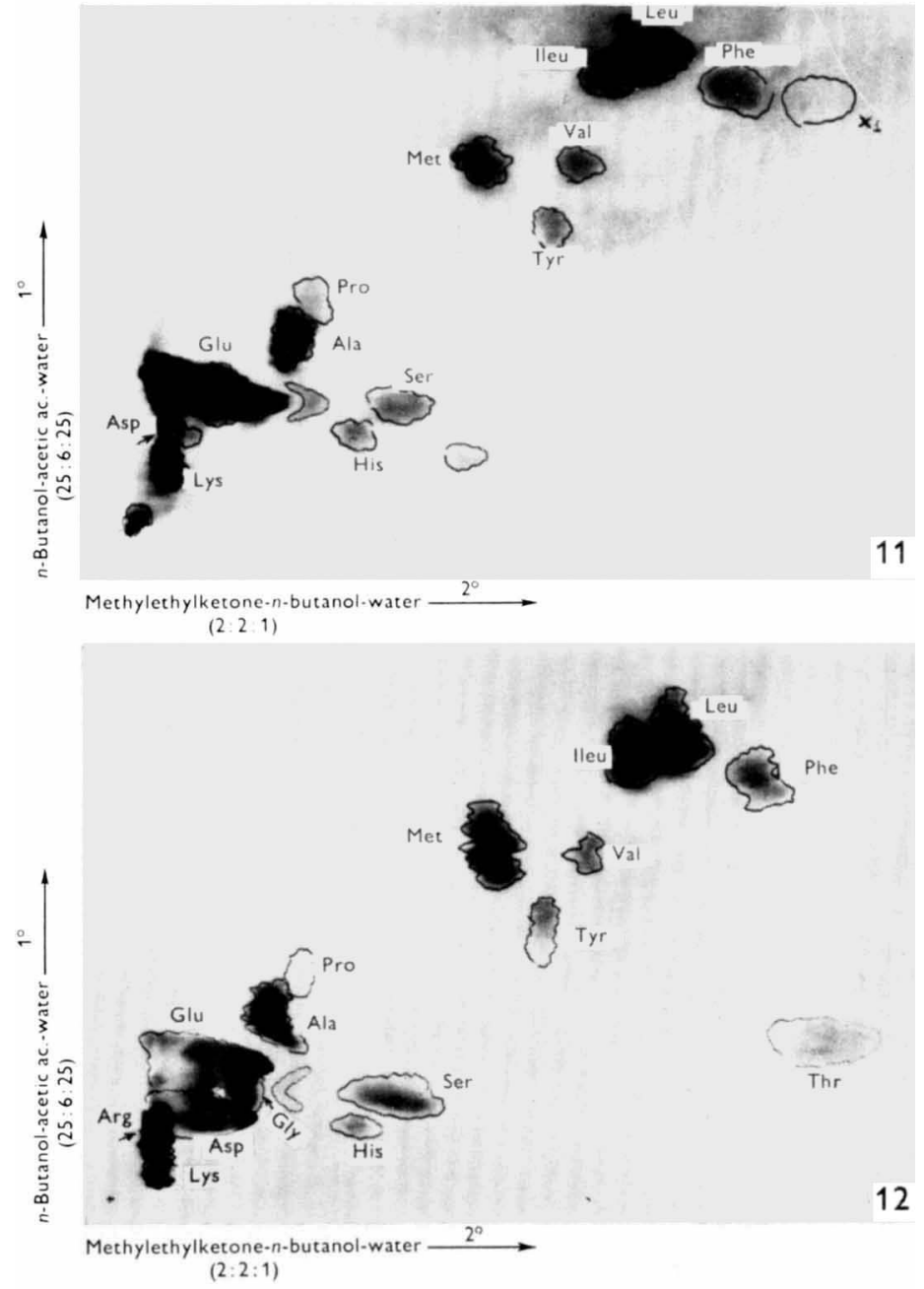